\title{
Evaluation of retinal nerve fiber layer thickness and macular thickness in amblyopic children
}

\section{Ambliyop çocuklarda retina sinir lifi tabakası ve makula kalınlığının değerlendirilmesi}

\author{
Damla Cullha ${ }^{1}$, Mustafa Kemall Arıcı
}

University of Health Sciences, Șișli Hamidiye Etfal Teaching and Research Hospital Halaskargazi Avenue, İstanbul, Turkey

2 Memorial Hospital, Ataşehir, Istanbul, Turkey.

Corresponding author: Damla Culha, MD, University of Health Sciences, Şişli Hamidiye Etfal Teaching and Research Hospital Halaskargazi Avenue, Istanbul, Turkey

E-mail:11katre12@gmail.com

Received/Accepted: November 09, 2020 / September 30, 2021

Conflict of interest: There is not a conflict of interest.

\section{SUMMARY}

Objective: To compare central macular and retinal nerve fiber layer (RNFL) thickness using Spectral Domain Optical Coherence Tomography (SD-OCT) among patients with hyperopic anisometropic, strabismic and mixed amblyopia and healthy controls.

Method: This prospective, cross-sectional study included 39 amblyopic children, their fellow eyes and 20 healthy individuals. Central macular and RNFL (superior, nasal, inferior and temporal quadrants and mean RNFL) thicknesses were measured with SD-OCT.

Results: Difference was not statistically significant in the central macular thickness when the anisometropic, strabismic and mixed amblyopia groups were compared among themselves, fellow eyes and healthy control group. In the anisometropic amblyopic group, the inferior RNFL and nasal RNFL values were significantly thicker compared to the fellow eyes $(\mathrm{p}=0.009$, $\mathrm{p}=0.028$, respectively). Mean RNFL measurements were significantly thicker in anisometropic and mixed groups in the amblyopic eyes compared to the fellow eyes $(\mathrm{p}=0.009, \mathrm{p}=0.031$, respectively). In the temporal quadrant, the RNFL was found to be statistically significantly thinner in the anisometropic and mixed amblyopic groups compared to the fellow eyes ( $\mathrm{p}=0.049, \mathrm{p}=0.010$, respectively).

Conclusions: There was no considerably difference in the central macular thickness among the amblyopia groups, fellow eyes and healthy controls. However, significant changes were found in the mean RNFL and certain quadrants of the RNFL thicknesses in the anisometropic and mixed amblyopic groups.

Keywords: Amblyopia, macular thickness, optical coherence tomography, retinal nerve fiber layer thickness
Damla Culha

Mustafa Kemal Arıcı

ORCID IDs of the authors: D.C. $0000-0002-0678-135 \mathrm{X}$

M.K.A. 0000-0002-6350-9723

\section{ÖZET}

Amaç: Hipermetropik anizometropik, strabismik ve mikst ambliyop çocuklar ile sağlıklı kontrol grubu arasında Spektral Domain Optik Koherens Tomografi (SD-OKT) ile makula kalınlığı ve retina sinir lifi tabakası (RSLT) kalınlığının karşılaștırılması amaçlandı.

Yöntem: Bu prospektif kesitsel çalışmaya 39 ambliyop çocuk, onların diğer gözleri ve 20 sağlıklı çocuk dahil edildi. SD-OKT ile santral makular ve RSLT (üst, nazal, alt ve temporal kadranlar ile ortalama RSLT) kalınlıkları ölçüldü. Bulgular: Hipermetropik anizometropik, strabismik ve mikst ambliyop gruplar kendi aralarında, diğer gözleriyle ve sağlıklı kontrol grubuyla karşılaştırıldığında santral makula kalınlığında istatistiksel olarak anlamlı bir fark saptanmadı. 
Anizometropik grupta ambliyop gözlerin alt ve nazal kadran RSLT kalınlığı diğer gözlerinden anlamlı olarak kalın saptand 1 ( $\mathrm{p}=0.009, \mathrm{p}=0.028$, sırasıyla). Ortalama RSLT kalınlı̆̆1 anizometropik ve mikst gruplarda ambliyop gözlerde diğer gözleriyle karşılaştırıldığında anlamlı olarak kalın bulundu ( $\mathrm{p}=0.009, \mathrm{p}=0.031$, sırasıyla). Anizometropik ve mikst gruplarda, ambliyop gözlerin temporal kadran RSLT kalınlığı diğer gözlerinden istatistiksel olarak anlamlı oranda ince saptand $(\mathrm{p}=0.049, \mathrm{p}=0.010$, sirasiyla) .

Sonuç: Ambliyop gruplar, diğer gözleri ve sağlıklı kontrol grubu arasında santral makula kalınlığı açısından anlamlı fark saptanmadı. Bununla beraber anizometropik ve mikst ambliyop gruplarda RSLT'nin bazı kadranları ve ortalama RSLT kalınlığında anlamlı farklılıklar bulundu.

Anahtar sözcükler: Ambliyopi, makula kalınlığı, optik koherens tomografi, retina sinir lifi tabakası kalınlığı

\section{INTRODUCTION}

Amblyopia is defined as the decrease in the bestcorrected visual acuity in one eye or both eyes, due to abnormal binocular interaction without an organic disorder. It usually occurs owing to anisometropia, strabismus, deprivation/occlusion amblyopia or the combination of the two ${ }^{1}$. The prevalence has an average ranging from $0.2 \%$ to $5.3 \%$ in the world, varying according to the society and age groups ${ }^{2}$. In the studies carried out in Turkey, the prevalence was found to be between $1.1 \%$ and $5.5 \%{ }^{3,4}$.

The studies of amblyopia, conducted by Hubel and Wiesel on animal models in the 1960s, demonstrated histopathological changes in the visual cortex and lateral geniculate nucleus (LGN) 5,6 . With the introduction of functional magnetic resonance imaging (MRI), morphological and functional deficits have been presented in the LGN, striate cortex and extrastriate cortex in the humans with amblyopia ${ }^{7-9}$. The changes occurring in the retina and optic nerve in the case of amblyopia have been researched from past to present, and there is no approved results have been reached so far ${ }^{10-13}$.

Since the introduction of the Optical Coherence Tomography (OCT) device, many studies have investigated the morphological changes occurring in both the macula and the retinal nerve fiber layer (RNFL) thickness in different age groups as well as the amblyopia of different etiology. There are studies reporting no difference in the central macular and RNFL thickness, while the macula and RNFL were found to be thicker in some studies ${ }^{14-18}$.

OCT, which is a non-contact, non-invasive and easily applicable technique, has been guide in the diagnosis and treatment of many diseases affecting the retina, choroid and optic disc. The Spectral Domain Optical Coherence Tomography (SD-OCT) has made possible much more detailed analysis with the improved spatial resolution and scan rapidity.
In this study, we aimed to examine the central macular thickness, the thickness of the four quadrants and mean RNFL thickness by using SD-OCT in strabismic, anisometropic and mixed amblyopic children, comparing the groups among themselves, with the fellow eyes and healthy control group.

\section{MATERIAL AND METHODS}

This study was conducted at the Department of Ophthalmology at Cumhuriyet University Medical School. Prior approval from the Institutional Review Board of the institute was taken and written informed consent was obtained from each subject. The study was performed in adherence to the Declaration of Helsinki.

Ten hypermetropic anisometropic amblyopic patients, 17 strabismic amblyopic patients, 12 mixed amblyopic patients, their fellow eyes and 20 healthy subjects were included in the study. Unilateral amblyopia was defined as a bestcorrected visual acuity (BCVA) of at least a twoline difference between the amblyopic and fellow eyes with a visual acuity 20/20 by Snellen chart.

Hypermetropic anisometropic amblyopia was defined as hyperopia of $\geq 1.5 \mathrm{D}$, an intraocular difference of at least $1.5 \mathrm{D}$ (spherical equivalent). Cases with strabismus were excluded. Strabismic amblyopia was defined as amblyopia in the presence of an eye misalignment of $>8$ prism diopters. The difference in refractive errors between the two eyes was $<1$ diopter in spherical or cylindrical force to eliminate anisometropia. The cases with strabismus and hypermetropic anisometropia formed the mixed amblyopia group. Controls were selected from patients applied for routine ophthalmic examination who had 20/20 visual acuity and no ocular or systemic disease. Only one eye of each control was included.

Patients with histories of systemic disease, previous ocular surgery, ocular trauma, intraocular pressure of $>21 \mathrm{mmHg}$, evidence of cataract or glaucoma, dry eye, or any corneal, 
retinal, or choroidal pathology were excluded from the study.

All patients underwent a full ophthalmological assessment, including BCVA testing, cycloplegic refraction, slit-lamp biomicroscopy, fundus examination, cover-uncover and prism cover test, extraocular movements and SD-OCT (NIDEK RS-3000 Advance, Tokyo, Japan) examination. OCT measurements were obtained for all patients and controls following full ophthalmic examination. After the completion of the process, the central macular thickness was manually measured with the assistance of calipers. All measurements and manual calculations were done by the same ophthalmologist (D.C.).

Mean, standard deviation, median, minimum, maximum, frequency and ratio values were used in the descriptive statistics of the data. The distribution of the variables was measured by using the Kolmogorov Smirnov test. KruskalWallis and Mann-Whitney U tests were used for the analysis of the quantitative independent data. Wilcoxon test was used for the analysis of the dependent quantitative data. The qualitative independent data were analyzed using the Chisquare test. Statistical analyses were performed by using SPSS 26.0 software. The p-value of $<0.05$ was considered statistically significant.

\section{RESULTS}

There were no significant differences among the amblyopic groups and control group with respect to age or sex $(\mathrm{p}=0.060$ and $\mathrm{p}=0.726$, respectively). Table 1 shows demographic data.
The central macular thickness was $198.9 \pm 16.1 \mu \mathrm{m}$ in anisometropic hyperopic amblyopic group and $192.7 \pm 8.6 \mu \mathrm{m}$ in fellow; 197.4 $\pm 13.8 \mu \mathrm{m}$ in strabismic amblyopic group and $196.5 \pm 14.0 \mu \mathrm{m}$ in fellow; $199.4 \pm 10.7 \mu \mathrm{m}$ in mixed amblyopic group and $195.4 \pm 9.2 \mu \mathrm{m}$ in fellow; 193.9 $\pm 4.6 \mu \mathrm{m}$ in control group. The central macular thickness of the amblyopic eyes in the anisometropic, strabismic and mixed groups was higher compared to the control group; however, this difference was not statistically significant.

The data regarding the central macular thickness, mean and four quadrant RNFL values of the groups are presented in Table 2.

The mean RNFL was significantly higher in the anisometropic and mixed groups in the amblyopic eye compared to the fellow eye $(\mathrm{p}=0.009$, $\mathrm{p}=0.031$, respectively); however, there was no remarkable difference in the strabismic group ( $>>0.05)$.

No significant difference was found between the groups regarding the RNFL in the superior quadrant $(\mathrm{p}>0.05)$. However, the thickness of the amblyopic eyes in the inferior and nasal quadrants was significantly thicker in the anisometropic group compared to the fellow eyes $(\mathrm{p}=0.009$, $\mathrm{p}=0.028$, respectively). In the temporal quadrant, RNFL was considerably thinner in the anisometropic and mixed groups $(\mathrm{p}=0.049$, $\mathrm{p}=0.010$, respectively) compared to the fellow eyes; however, no difference was found in the strabismic group ( $p>0.05)$.

Table 1: Demographic data of enrolled patients

\begin{tabular}{|c|c|c|c|c|c|c|c|c|c|c|c|c|c|c|c|c|c|c|}
\hline & & \multicolumn{4}{|c|}{ Anisometropic } & \multicolumn{4}{|c|}{ Strabismic } & \multicolumn{4}{|c|}{ Mixed } & \multicolumn{4}{|c|}{ Control } & \multirow{3}{*}{$\begin{array}{l}\mathrm{p} \\
0,060\end{array}$} \\
\hline & & \multicolumn{3}{|c|}{ Mean $\pm \mathrm{sd} / \mathrm{n}-\%$} & \multirow{2}{*}{$\begin{array}{l}\text { Med } \\
9\end{array}$} & \multicolumn{3}{|c|}{ Mean $\pm \mathrm{sd} / \mathrm{n}-\%$} & \multirow{2}{*}{$\begin{array}{l}\text { Med } \\
9\end{array}$} & \multicolumn{3}{|c|}{ Mean $\pm \mathrm{s} d / \mathrm{n}-\%$} & \multirow{2}{*}{$\begin{array}{l}\text { Med } \\
10\end{array}$} & \multicolumn{3}{|c|}{ Mean $\pm \mathrm{s} d / \mathrm{n}-\%$} & \multirow{2}{*}{$\begin{array}{l}\text { Med } \\
11\end{array}$} & \\
\hline Age & & 9,20 & \pm & 2,74 & & 9,00 & \pm & 2,21 & & 9,50 & \pm & 2,47 & & 11,10 & \pm & 2,65 & & \\
\hline Sex & female & 6 & & $60,0 \%$ & & 7 & & $41,2 \%$ & & 6 & & $50,0 \%$ & & 8 & & $40,0 \%$ & & 0,726 \\
\hline & male & 4 & & $40,0 \%$ & & 10 & & $58,8 \%$ & & 6 & & $50,0 \%$ & & 12 & & $60,0 \%$ & & \\
\hline
\end{tabular}


Table 2: Central macular thickness, mean and four quadrant RNFL values of the groups

\begin{tabular}{|c|c|c|c|c|c|c|c|c|c|c|c|c|c|c|c|c|c|c|}
\hline & \multicolumn{4}{|c|}{ Anisometropic } & \multicolumn{4}{|c|}{ Strabismic } & \multicolumn{4}{|c|}{ Mixed } & \multicolumn{4}{|c|}{ Control } & \multicolumn{2}{|l|}{$\mathrm{p}$} \\
\hline \multicolumn{18}{|l|}{$\begin{array}{l}\text { Central } \\
\text { macula }(\mu \mathrm{m})\end{array}$} & \\
\hline Amblyopic eye & 198,9 & \pm & 16,1 & 190 & 197,4 & \pm & 13,8 & 194 & 199,4 & \pm & 10,7 & 198 & 193,9 & \pm & 4,6 & 194 & 0,744 & K \\
\hline Fellow eye & 192,7 & \pm & 8,6 & 196 & 196,5 & \pm & 14,0 & 194 & 195,4 & \pm & 9,2 & 196 & 193,9 & \pm & 4,6 & 194 & 0,920 & K \\
\hline \multicolumn{19}{|l|}{$\begin{array}{l}\text { Superior } \\
R N F L(\mu \mathrm{m})\end{array}$} \\
\hline Amblyopic eye & 142,9 & \pm & 17,5 & 145 & 131,9 & \pm & 19,2 & 130 & 152,3 & \pm & 23,6 & 150 & 139,2 & \pm & 16,0 & 140 & 0,110 & K \\
\hline \multirow[t]{2}{*}{ Fellow eye } & 148,7 & \pm & 22,8 & 152 & 138,1 & \pm & 13,7 & 136 & 145,3 & \pm & 16,0 & 144 & 139,2 & \pm & 16,0 & 140 & 0,299 & K \\
\hline & \multicolumn{3}{|l|}{0,444} & w & \multicolumn{3}{|l|}{0,064} & w & \multicolumn{3}{|l|}{0,285} & w & & & & & & \\
\hline \multirow[t]{2}{*}{ Fellow eye } & 137,0 & \pm & 20,7 & 136 & 139,3 & \pm & 19,6 & 146 & 134,3 & \pm & 24,1 & 141 & 144,5 & \pm & 22,1 & 145 & 0,653 & K \\
\hline & \multicolumn{3}{|l|}{0,009} & w & \multicolumn{3}{|l|}{0,162} & w & \multicolumn{3}{|l|}{0,075} & w & & & & & & \\
\hline \multicolumn{19}{|l|}{$\begin{array}{l}\text { Nasal } \\
\text { RNFL }(\mu \mathrm{m})\end{array}$} \\
\hline Amblyopic eye & 99,3 & \pm & 16,2 & 101 & 88,2 & \pm & 16,4 & 88 & 86,8 & \pm & 15,5 & 85 & 90,5 & \pm & 11,1 & 89 & 0,299 & $\mathrm{~K}$ \\
\hline \multirow[t]{2}{*}{ Fellow eye } & 83,8 & \pm & 22,5 & 71 & 90,0 & \pm & 14,3 & 96 & 77,1 & \pm & 15,4 & 82 & 90,5 & \pm & 11,1 & 89 & 0,120 & K \\
\hline & 0,028 & & & w & 0,602 & & & w & 0,084 & & & w & & & & & & \\
\hline $\begin{array}{l}\text { Temporal } \\
R N F L(\mu \mathrm{m})\end{array}$ & & & & & & & & & & & & & & & & & & \\
\hline Amblyopic eye & 118,0 & \pm & 9,1 & 116 & 108,8 & \pm & 12,7 & 111 & 115,6 & \pm & 11,1 & 113 & 110,8 & \pm & 9,7 & 112 & 0,155 & K \\
\hline Fellow eye & 111,1 & \pm & 11,8 & 110 & 107,6 & \pm & 9,7 & 109 & 109,2 & \pm & 9,1 & 109 & 110,8 & \pm & 9,7 & 112 & 0,885 & $\mathrm{~K}$ \\
\hline & 0,009 & & & w & 0,477 & & & w & 0,031 & & & w & & & & & & \\
\hline
\end{tabular}

${ }^{\mathrm{K}}$ Kruskal-wallis (Mann-whitney u test) $/{ }^{\mathrm{w}}$ Wilcoxon test

Sd:standard deviation med:median

\section{DISCUSSION}

In the present study, we examined the central macular thickness, RNFL in the four quadrants and mean RNFL in hypermetropic anisometropic, strabismic and mixed amblyopic children, comparing them with the fellow eyes and healthy children. The mean central macular thickness was higher in the amblyopia groups compared to the control group but this difference was not statistically significant. The mean RNFL thickness of the amblyopic eyes in the anisometropic and mixed amblyopia groups was found thicker compared to the fellow eyes. When the strabismic amblyopia group was compared with the fellow eyes and the control group and no significant difference was found in the four quadrants in terms of the RNFL and mean RNFL thickness. 
In a study conducted by Firat et al. on 36 children with anisometropic and strabismic amblyopia and 32 healthy children, in the same geographical region as the present study (Malatya/Turkey) and with the same OCT device (Nidek-RS-3000), no considerable difference was observed in the central macular thicknesses of the amblyopia, fellow and control groups ${ }^{19}$. In another study conducted with the same ethnic group and using the same OCT device, adults with anisometropic amblyopia were compared to the fellow eyes and the control group and no difference was found in central macular thickness among the groups ${ }^{18}$. Similar to our study, Alotaibi et al. carried out a study on a total of 93 children with anisometropic, strabismic and mixed amblyopia. When compared with the fellow eyes, they did not find any difference in the macular thickness in all 3 amblyopia groups; however, the thickness of the RNFL in the amblyopic eye was thicker in all 3 groups compared to the fellow eyes. In the present study, where we did not find any differences in the strabismic amblyopia group in terms of the mean RNFL thickness, the other results were similar to the results of the study by Alotaibi et al 14

There are also many studies reporting the central macular thickness significantly higher in amblyopic eyes ${ }^{15,16,20,21}$. Bruce et al. compared 85 anisometropic, strabismic and mixed amblyopic eyes with fellow eyes and they did not find any difference in the foveal thickness. However, there was an increase in the foveal thickness and decrease in the foveal pit depth when compared to the control group ${ }^{20}$. Rajavi et al. stated that amblyopic eyes were thicker compared to the fellow eyes and the healthy control group, and that the difference in thickness increased as the depth of amblyopia increased ${ }^{15}$. On the other hand, there are studies demonstrating that macula is detected thicker in anisometropic amblyopia without the presence of a significant difference in the strabismic amblyopia ${ }^{22,23}$; and there are also studies presenting that the macula of strabismic amblyopia is thicker without the presence of a difference in the anisometropic amblyopia ${ }^{24,25}$.

In their study conducted with 74 adults with anisometropic amblyopia and 78 healthy adults, Sahin et al. found an increase in the thickness of the nasal RFNL and a decrease in the thickness of the temporal RNFL, similar to our present study ${ }^{26}$. This study, which found that RNFL was thicker in hypermetropic anisometropia groups in all quadrants and thinner in myopic anisometropia groups, may explain why the mean RNFL was found thicker in anisometropic and mixed amblyopia groups, and why there was no difference in the strabismic group in the present study, which included hypermetropic children specifically. Similarly, Yen et al. studied 38 patients with amblyopia and found no difference in the strabismic amblyopic eyes compared to the fellow eyes, while the RNFL was thicker in the refractive amblyopia group compared to the fellow eyes ${ }^{27}$. In their study where the amblyopic eyes of the hypermetropic anisometropic were compared to the fellow eyes, Yoon et al. found that the RNFL was thicker in amblyopic eyes compared to the fellow eyes. However, they stated no difference in the macular thickness ${ }^{28}$. Despite these, there are studies reporting no difference in the RNFL thickness ${ }^{18,19,22-24}$.

Some studies have demonstrated that the RNFL and central macular thickness could be associated with the axial length and refractive error. Having studied the RNFL thickness in healthy children, Salchow et al found that there was an increase of $1.7 \mu \mathrm{m}$ in RNFL thickness per each increase by $1 \mathrm{D}$ in the hypermetropic value ${ }^{29}$. In their study on the heathy adults, Budenz et al. reported that the RNFL thickness decreased about $2.2 \mu \mathrm{m}$ per each increase of $1 \mathrm{~mm}$ in the axial length ${ }^{30}$. In two separate studies conducted with adults and children, it was observed that the axial length was negatively correlated with the RNFL thickness; and when the Littmann formula was used to correct the magnification effect, there was no significant difference in the RNFL thickness among the myopic, hypermetropic and emmetropic groups ${ }^{31,32}$. In two other studies, no significant difference was found among the myopic, hypermetropic and emmetropic groups in terms of the RNFL thickness after the Littmann's formula, except for the temporal quadrant. It was found that the thickness of the temporal quadrant increased with the increase of the axial length ${ }^{33,34}$. This finding may explain the thinness of the temporal quadrant in the hypermetropic anisometropic and mixed amblyopia groups in our study. According to Kusbeci, the reason why RNFL was found to be thick in the studies was that the magnification effect was not corrected, since the majority of the amblyopia cases was hypermetropic ${ }^{35}$. The magnification effect may be the reason why we found the mean RNFL thicker in the anisometropic and mixed amblyopia groups in our study, in which we included only hypermetropic patients in both anisometropic and mixed amblyopia groups and did not apply the Littmann's formula. On the other hand, in the study comparing the axial length and macular thickness in children with anisometropic amblyopia, strabismic amblyopia and healthy 
children, Kok et al. found no difference in the macular thickness of the three groups despite the fact that the axial lengths of the amblyopic and fellow eyes were significantly shorter compared to the control group and stated that the correlation between the axial length and macular thickness in healthy people was not present in the amblyopic and fellow eyes ${ }^{36}$. Yassin et al. found no significant differences in the RNFL thicknesses of the persistent and recovered children with amblyopia, stating that the refractive error had no relationship with the macular and RNFL thickness ${ }^{37}$. There are other studies indicating that there is no significant correlation between the RNFL thickness and axial length in amblyopia groups 27,38

Yen et al. suggested that the normal postnatal reduction (apoptosis) of the retinal ganglion cells was interrupted in amblyopia, thereby leading to the increase in the RNFL thickness in amblyopia 27. Huynh et al. and Pang et al. also stated that the pause of normal postnatal changes and the interruption of the henle layer organization and foveal maturation may cause an increase in foveal thickness in amblyopia ${ }^{39,40}$. A recent study supported this hypothesis, demonstrating that the visual deprivation induced molecular, cellular and functional changes by affecting the postnatal differentiation in the retina ${ }^{13}$. This raises the question of whether there is a change in the macular and RNFL thickness after the treatment. Pang et al, who reported that the fovea, which is thicker than the fellow eye in children with myopic anisometropic amblyopia, became thinner after the treatment, and stated that the treatment of amblyopia can reverse these changes occurring in the central macula ${ }^{40}$. Kavitha et al. followed up 30 children with anisometropic amblyopia for a period of 1 year in their study, and concluded that the macular and foveal thickness, which was higher in the amblyopic eyes, decreased with the increase in the BCVA. They presented that the decrease in the foveal thickness was significant between the ages of 5-10, while the decrease in macular thickness was more pronounced between the ages of 11-15 ${ }^{41}$. In their study, Huynh et al. compared the amblyopic and healthy children, concluding that the foveal thickness was significantly higher in the amblyopic eyes compared to the fellow and control groups, and the difference in thickness was more pronounced in children who did not receive any treatment ${ }^{39}$. Similarly, Tugcu et al. classified the amblyopic children, who started treatment before the age of 4 and received treatment for at least 4 years, as persistent and resolved amblyopia, and compared them with the healthy children. While there was no difference in foveal thickness between persistent and resolved amblyopic eyes, they found higher foveal thickness in both amblyopia groups compared to the control group ${ }^{42}$. Yoon et al. found no difference in the foveal thickness after treatment; however, they determined a significant decrease in the foveal volume ${ }^{43}$. In our study, the mean central macular thickness in the amblyopia groups was higher compared to the control group; however, it was not statistically significant. This may be due to the fact that all of the amblyopic patients we included in our study were the children who had been treated and followed-up in our clinic for a certain period of time. In these studies mentioned above, there was no difference between amblyopic eyes, fellow eyes and the control group in terms of the RNFL thickness before and after the treatment $39,41,42$. Chen et al. found the mean RNFL thicker in the current and previous amblyopia groups. However, after the correction made according to the axial length and refractive error, this difference was not significant and the RNFL thickness had a strong correlation with the axial length and the refractive error $^{44}$.

The examination of three different groups and the presence of the healthy control group could be considered as the strength of the present study; however, the insufficiency of the sample size is one of the significant limitations. Another important limitation is that the axial length was not measured, and the resulting magnification effect could not be corrected. Other limitations are the inclusion of only the hypermetropic patients, the absence of a separate myopic anisometropic group and the measurement of the central macula, which was performed manually using calipers due to the absence of an automated program.

\section{CONCLUSION}

As a result, no significant difference was found in central macula thickness when the hyperopic anisometropic, strabismic and mixed amblyopic eyes were compared with the fellow eyes and the healthy control group. In hypermetropic anisometropic and mixed amblyopia, the mean RNFL is significantly thicker compared to the fellow eyes, while the RNFL is significantly thinner in the temporal quadrant compared to the fellow eyes. In anisometropic amblyopia, RFNL was significantly thicker in the nasal and inferior quadrants compared to the fellow eyes. In strabismic amblyopia, no difference was observed in the quadrants of RNFL or mean RNFL thickness compared to the fellow and control groups. 
Acknowledgments: Cumhuriyet University (Scientific Research Project) (T-621)

Conflict of Interest: None.

\section{REFERENCES}

1. Von Noorden GK, Campos EC. Examination of the Patient 4:Amblyopia. In: Lampert R, Cox K, Burke D, eds. Binocular Vision and Ocular Motility. 6th ed. United States of America; Mosby Harcourt; 2002:246-87.

2. Attebo K, Mitchell P, Cumming R, Smith W, Jolly N, Sparkes R. Prevalence and causes of amblyopia in an adult population. Ophthalmo logy. 1998;105 (1):154-159.

3. Gursoy H, Basmak H, Yaz Y, Colak E. Vision screening in children entering school: Eskisehir, Turkey. Ophthalmic Epidemiol. 2013;20(4):232-238.

4. Azizoğlu S, Crewther SG, Şerefhan F, Barutchu A, Göker S, Junghans BM. Evidence for the need for vision screening of school children in Turkey. BMC Ophthalmol. 2017;17(1):230.

5. Wiesel TN, Hubel DH. Effects of Visual Deprivation on Morphology and Physiology of Cells in the Cats Lateral Geniculate Body. J Neurophysiol. 1963;26:978-993.

6. Wiesel TN, Hubel DH. Single-cell Responces in Striate Cortex of Kittens Deprived of Vision in One Eye.J Neurophysiol. 1963;26:1003-1017.

7. Barnes GR, Hess RF, Dumoulin SO, Achtman RL, Pike GB. The cortical deficit in humans with strabismic amblyopia. $J$ Physiol. 2001;533(Pt 1):281-297.

8. Mendola JD, Conner IP, Roy A, et al. Voxelbased analysis of MRI detects abnormal visual cortex in children and adults with amblyopia. Hum Brain Mapp. 2005;25 (2):222-236

9. Hess RF, Thompson B, Gole G, Mullen KT. Deficient responses from the lateral geniculate nucleus in humans with amblyopia. Eur J Neurosci. 2009;29(5):10641070.

10. Lempert P. Retinal area and optic disc rim area in amblyopic, fellow, and normal hyperopic eyes: a hypothesis for decreased acuity in amblyopia. Ophthalmology. 2008;115(12):2259-2261 .
11. Chen W, Lou J, Thorn F, et al. Retinal Microvasculature in Amblyopic Children and the Quantitative Relationship Between Retinal Perfusion and Thickness. Invest Ophthalmol Vis Sci. 2019;60(4):1185-1191.

12. Pineles SL, Demer JL. Bilateral abnormalities of optic nerve size and eye shape in unilateral amblyopia. $A m \quad J$ Ophthalmol. 2009;148 (4):551-557.e2.

13. Prokosch-Willing V, Meyer zu Hoerste M, Mertsch S, Stupp T, Thanos S. Postnatal visual deprivation in rats regulates several retinal genes and proteins, including differentiation-associated fibroblast growth factor-2. Dev Neurosci. 2015;37(1):14-28.

14. Alotaibi AG, Al Enazi B. Unilateral amblyopia: Optical coherence tomography findings. Saudi J Ophthalmol. 2011;25(4): 405-409.

15. Rajavi Z, Sabbaghi H, Behradfar N, Yaseri M, Aghazadeh Amiri M, Faghihi M. Macular Thickness in Moderate to Severe Amblyopia. Korean $J \quad$ Ophthalmol. 2018;32(4):312-318.

16. Kasem MA, Badawi AE. Changes in macular parameters in different types of amblyopia: optical coherence tomography study. Clin Ophthalmol. 2017;11:1407-1416.

17. Lekskul A, Wuthisiri W, Padungkiatsagul T. Evaluation of retinal structure in unilateral amblyopia using spectral domain optical coherence tomography. J AAPOS. 2018;22 (5):386-389.

18. Kantarci FA, Tatar MG, Uslu H, et al. Choroidal and peripapillary retinal nerve fiber layer thickness in adults with anisometropic amblyopia [published correction appears in Eur J Ophthalmol. 2016 Dec 29;27(1):113]. Eur $J \quad$ Ophthalmol. 2015;25 (5):437-442.

19. Firat PG, Ozsoy E, Demirel S, Cumurcu T, Gunduz A. Evaluation of peripapillary retinal nerve fiber layer, macula and ganglion cell thickness in amblyopia using spectral optical coherence tomography. Int $J$ Ophthalmol. 2013;6(1):90-94.

20. Bruce A, Pacey IE, Bradbury JA, Scally AJ, Barrett BT. Bilateral changes in foveal structure in individuals with amblyopia. Ophthalmology. 2013;120(2):395-403.

21. Tekin K, Kızıltoprak H, İnanç M, Şekeroglu MA. Evaluation of Retinal Layers in 
Hyperopic Anisometropic Amblyopia by Optical Coherence Tomography Segmentation Analysis. Turkiye Klinikleri J Ophthalmol. 2020;29(3):192-8.

22. Sefi-Yurdakul N, Cosar A, Koc F. Retinal Nerve Fiber Layer and Macular Thickness in Patients with Strabismic and Anisohypermetropic Amblyopia. Turkiye Klinikleri J Ophthalmol 2014;23(4):201-6

23. Andalib D, Javadzadeh A, Nabai R, Amizadeh Y. Macular and retinal nerve fiber layer thickness in unilateral anisometropic or strabismic amblyopia. J Pediatr Ophthalmol Strabismus. 2013;50(4):218-221.

24. Dickmann A, Petroni S, Salerni A, Dell'Omo R, Balestrazzi E. Unilateral amblyopia: An optical coherence tomography study. J AAPOS. 2009;13(2):148-150.

25. Agrawal S, Singh V, Singhal V. Crosssectional study of macular thickness variations in unilateral amblyopia. J Clin Ophthalmol Res 2014;2:15-7.

26. Sahin G, Dal D. Analysis of retinal nerve fiber layer thickness in anisometropic amblyopia via optic coherence tomography. Graefes Arch Clin Exp Ophthalmol. 2019;257 (10):2103-2110.

27. Yen MY, Cheng CY, Wang AG. Retinal nerve fiber layer thickness in unilateral amblyopia. Invest Ophthalmol Vis Sci. 2004;45(7):2224-2230.

28. Yoon SW, Park WH, Baek SH, Kong SM. Thicknesses of macular retinal layer and peripapillary retinal nerve fiber layer in patients with hyperopic anisometropic amblyopia. Korean J Ophthalmol. 2005;19(1): 62-67.

29. Salchow DJ, Oleynikov YS, Chiang MF, et al. Retinal nerve fiber layer thickness in normal children measured with optical coherence tomography. Ophthalmology. 2006;113(5):786-791.

30. Budenz DL, Anderson DR, Varma R, et al. Determinants of normal retinal nerve fiber layer thickness measured by Stratus OCT [published correction appears in Ophthalmology. 2008 Mar;115(3):472]. Ophthalmology. 2007;114(6):1046-1052.

31. Oner V, Aykut V, Tas M, Alakus MF, Iscan Y. Effect of refractive status on peripapillary retinal nerve fibre layer thickness: a study by RTVue spectral domain optical coherence tomography. $\mathrm{Br} \quad \mathrm{J} \quad$ Ophthalmol. 2013;97(1):75-79.

32. Öner V, Özgür G, Türkyilmaz K, Şekeryapan B, Durmus M. Effect of axial length on retinal nerve fiber layer thickness in children. Eur J Ophthalmol. 2014;24(2):265-272.

33. Aykut V, Öner V, Taş M, Işcan $Y$, Ağaçhan A. Influence of axial length on peripapillary retinal nerve fiber layer thickness in children: a study by RTVue spectral-domain optical coherence tomography. Curr Eye Res. 2013;38(12):1241-1247.

34. Savini G, Barboni P, Parisi V, Carbonelli M. The influence of axial length on retinal nerve fibre layer thickness and optic-disc size measurements by spectral-domain OCT. Br J Ophthalmol. 2012;96(1):57-61.

35. Kusbeci T, Karti O, Karahan E, Oguztoreli M. The Evaluation of Anatomic and Functional Changes in Unilateral Moderate Amblyopic Eyes Using Optical Coherence Tomography and Pupil Cycle Time. Curr Eye Res. 2017;42(12):1725-1732.

36. Kok PH, de Kinkelder R, BraaksmaBesselink YC, et al. Anomalous relation between axial length and retinal thickness in amblyopic children. J AAPOS. 2013;17(6):598-602.

37. Yassin SA, Al-Tamimi ER, Al-Hassan S. Macular and retinal nerve fiber thickness in recovered and persistent amblyopia. Int Ophthalmol. 2015;35(6):833-842.

38. Miki A, Shirakashi M, Yaoeda K, et al. Retinal nerve fiber layer thickness in recovered and persistent amblyopia. Clin Ophthalmol. 2010;4:1061-1064.

39. Huynh SC, Samarawickrama C, Wang XY, et al. Macular and nerve fiber layer thickness in amblyopia: the Sydney Childhood Eye Study. Ophthalmology. 2009;116(9):16041609.

40. Pang Y, Frantz KA, Block S, Goodfellow GW, Allison C. Effect of Amblyopia Treatment on Macular Thickness in Eyes With Myopic Anisometropic Amblyopia. Invest Ophthalmol Vis Sci. 2015;56(4):2677-2683.

41. Kavitha V, Heralgi MM, Harishkumar PD, Harogoppa S, Shivaswamy HM, Geetha H. Analysis of macular, foveal, and retinal nerve fiber layer thickness in children with unilateral anisometropic amblyopia and their 
changes following occlusion therapy. Indian J Ophthalmol. 2019;67(7):1016-1022.

42. Tugcu B, Araz-Ersan B, Erdogan ET, et al. Structural and functional comparison of the persistent and resolved amblyopia. Doc Ophthalmol. 2014;128(2):101-109.

43. Yoon DH, Chun BY. Comparison of the Thickness and Volume of the Macula and Fovea in Patients with Anisometropic Amblyopia Prior to and after Occlusion Therapy. Korean J Ophthalmol. 2018;32(1): 52-58.

44. Chen W, Chen J, Huang J, Xu J, Zhang F, Lu F. Comparison of macular and retinal nerve fiber layer thickness in untreated and treated binocular amblyopia. Curr Eye Res. 2013;38(12):1248-1254. 